\title{
OXYGEN UPTAKE AND RESISTANCE EXERCISE METHODS: THE USE OF BLOOD FLOW RESTRICTION
}

\author{
CONSUMO DE OXIGÊNIO EMÉTODOS DE TREINO RESISTIDO: O USO DA RESTRIÇÃO \\ DEFLUXOSANGUÍNEO
}

Original Article

ARTIGO ORIGINAL

Artículo Original

\author{
CONSUMO DE OXIGENO Y MÉTODOS DE ENTRENAMIENTO RESISTIDO: USO DERESTRICIÓN \\ DEFLUJOSANGUÍNEO
}

\begin{abstract}
Adenilson Targino de Araújo Júnio (Physical Education Professional)

Maria do Socorro Cirilo-Sousa2,3,4 (Physical Education Professional)

Gabriel Rodrigues Neto ${ }^{5,6}$

(Physical Education Professional)

Rodrigo Poderoso ${ }^{7}$

(Physical Education Professional)

Geraldo Veloso Neto ${ }^{2}$

(Physical Education Professional)

Nuno Domingos Garrido ${ }^{8}$

(Physical Education Professional)

José Vilaça-Alves ${ }^{8}$

(Physical Education Professional)
\end{abstract}

1. Instituto Federal da Paraíba, IFPB, Physical Education Departament, Campina Grande, PB, Brazil. 2. Universidade Federal da Paraíba (UFPB), Associate Program of PostGraduation in Physical Education, João Pessoa, PB, Brazil.

3. Universidade Federal de

Pernambuco (UPE), Recife, PE, Brazil. 4. Universidade Regional do Cariri (URCA), Ceará, Brazil

5. Faculdade de Enfermagem Nova Esperança (FAMENE/ FACENE), Coordination of Physical Education, João Pessoa, PB, Brazil.

6. Centro de Ensino Superior e Desenvolvimento, Coordination of Physical Education, Center for Higher Education and Development, (CESED/UNIFACISA/ FCM), Campina Grande, PB, Brazil. 7. Universidade do Norte do Paraná, UNOPAR, Cascavel, PR, Brazil 8. Centro de Investigação em Desporto (CIDESD),Health Sciences an Human Development, Vila Real, Portugal.

\section{Correspondence:}

Universidade Federal da Paraíba (UFPB), Departamento de Educação Física, Laboratórios de Cineantropometria e Desenvolvimento Humano. Cidade Universitária, salas 06 e 08, João Pessoa, PB, Brazil. 58051-900. adenilsonjunior@yahoo.com.br

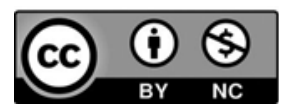

\begin{abstract}
Introduction: The literature has shown that a gap is identified regarding the acute effects of blood flow restriction training on aerobic variables. Objective: to analyze oxygen consumption $\left(\mathrm{VO}_{2}\right)$ during and after two resistance training sessions: traditional high intensity and low intensity with blood flow restriction. Methods:

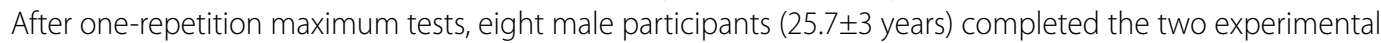
protocols, separated by 72 hours, in a randomized order: a) high intensity training at $80 \%$ of 1 RM (HIRE) and b) low intensity training at 20\% of 1RM combined with blood flow restriction (LIRE + BFR). Three sets of four exercises (bench press, squat, barbell bent-over row and deadlift) were performed. Oxygen consumption and excess post-exercise oxygen consumption were measured. Results: the data showed statistically significant differences between the traditional high intensity training and low intensity training with blood flow restriction, with higher values for traditional training sessions, except for the last five minutes of the excess post-exercise oxygen consumption. Oxygen consumption measured during training was higher $(p=0.001)$ for the HIRE (20.32 $\pm 1.46 \mathrm{~mL} \cdot \mathrm{kg}-1 \cdot \mathrm{min}-1)$ compared to the LIRE + BFR $(15.65 \pm 1.14 \mathrm{~mL} \cdot \mathrm{kg}-1 \cdot \mathrm{min}-1)$. Conclusion: Oxygen uptakes rates during and after the exercise sessions were higher for the high intensity training methodology. However, when taking into account the volume of training provided by both methods, these differences were attenuated. Level of Evidence III - Non-consecutive studies, or studies without consistently applied reference stand.
\end{abstract}

Keywords: Ischemia; Resistance training; Muscle strength; Heart rate.

\section{RESUMO}

Introdução: Na literatura, éidentificada uma lacuna em relação aos efeitos agudos do treino com restrição de fluxo sanguíneo sobre as variáveis aeróbicas. Objetivo: analisar o consumo de oxigênio $\left(\mathrm{VO}_{2}\right)$ durante e após duas sessões de treino de força: tradicional de alta intensidade e baixa intensidade com restrição do fluxo sanguíneo. Métodos: Após

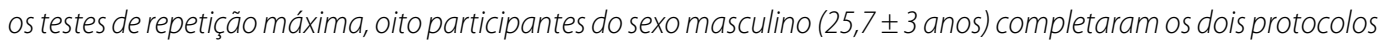
experimentais, separados por 72 horas, em ordem aleatória: a) treino de alta intensidade, com 80\% de 1RM (Al) e b) treino de baixa intensidade a 20\% de 1RM combinado com restrição de fluxo sanguíneo (BI + RFS). Três séries de quatro exercícios (supino, agachamento, remada inclinada e levantamento terra) foram realizadas. O consumo de oxigênio e o consumo de oxigênio em excesso pós-exercício foram medidos. Resultados: foram observadas diferenças estatisticamente significativas entre o treino tradicional de alta intensidade e de baixa intensidade com restrição de fluxo sanguíneo, com valores mais altos para sessões de treinamento tradicionais, exceto nos últimos cinco minutos para a medida de consumo de oxigênio pós-exercício. O $\mathrm{VO}_{2}$ medido durante o treino foi maior $(p=0.001)$ para a sessão de Al (20.32 $\pm 1.46 \mathrm{~mL} \cdot \mathrm{kg}-1 \cdot \mathrm{min}-1)$ comparada ao treino de Bl + RFS (15.65 $\pm 1.14 \mathrm{~mL} \cdot \mathrm{kg}-1 \cdot \mathrm{min}-1)$. Conclusão: O consumo de oxigênio durante e após as sessões de exercício foram maiores para a metodologia de treinamento de alta intensidade. Contudo, quando se considera o volume dos treinos, estas diferenças foram atenuadas. Nível de Evidência III - Estudos de pacientes não consecutivos; sem padrão de referência "ouro" aplicado uniformemente.

Descritores: Isquemia; Treinamento de resistência; Força muscular; Frequência cardíaca.

\section{RESUMEN}

Introducción: La literatura ha demostrado que se identifica una laguna con respecto a los efectos agudos del entrenamiento de restricción del flujo sanguíneo en las variables aeróbicas. Objetivo: analizar el consumo de oxígeno $\left(\mathrm{VO}_{2}\right)$ durante y después de dos sesiones de entrenamiento de fuerza: tradicional de alta intensidad y baja intensidad con res-

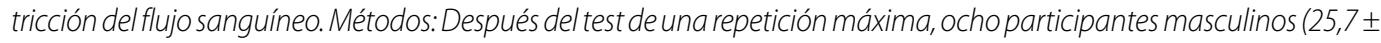
3 años) completaron los dos protocolos experimentales, separadas por 72 horas, en orden aleatorio: a) entren amiento de alta intensidad con 80\% de 1RM (Al) y b) entrenamiento de baja intensidad a 20\% de 1RM combinado con restricción del flujo sanguíneo (BI+RFS). Tres series de cuatro ejercicios (supino, sentadilla, remo con barray peso muerto), se realizaron. El consumo de oxígeno y el consumo de oxígeno en el exceso después del ejercicio se midieron. Resultados: se observaron diferencias estadísticamente significativas entre el entrenamiento tradicional de alta intensidad y de baja intensidad con restricción del flujo sanguíneo, con valores más altos para las sesiones de entrenamiento tradicionales, excepto os últimos 
cinco minutos del consumo de oxígeno en exceso post-ejercicio. ElVO $\mathrm{V}_{2}$ medido durante el entrenamiento fue mayor para el Al (20.32 $\pm 1.46 \mathrm{~mL} \cdot \mathrm{kg}-1 \cdot \mathrm{min}-1)$ en comparación con el BI + RFS (15.65 $\pm 1.14 \mathrm{~mL} \cdot \mathrm{kg}-1 \cdot \mathrm{min}-1)$. Conclusión: El consumo de oxígeno durante y después de las sesiones de ejercicio fueron mayores para la metodología de entrenamiento de alta intensidad. Sin embargo, cuando se considera el volumen de la práctica, se atenuaron estas diferencias. Nivel de Evidencia III - Estudios de pacientes no consecutivos; sin estándar de referencia "oro" aplicado uniformemente.

Descriptores: Isquemia; Entrenamiento de resistencia; Fuerza muscular; Frecuencia cardiaca.

\section{INTRODUCTION}

Low intensity resistance exercise with blood flow restriction (LIRE + BFR), or Kaatsu training, offers an alternative to traditional high intensity resistance exercise (HIRE), and although uses low loads, it produces similar strength gains and hypertrophy. ${ }^{1,2}$ However, has been poorly explored information on changes produced in aerobic capacity, including oxygen consumption $\left(\mathrm{VO}_{2}\right)$ and excess post-exercise oxygen consumption (EPOC).

Some authors have reported that blood flow restriction increases heart rate $(\mathrm{HR})_{1}^{3,4} \mathrm{EPOC}$, and $\mathrm{VO}_{2}$, but only in predominantly aerobic exercises. ${ }^{3-7}$ For resistance training, Tanimoto et al. ${ }^{8}$ observed that the level of oxygenation obtained with blood flow restriction is lower than that produced through other exercise regimens. Notwithstanding, concurrent improvements in oxygen uptake and other ventilatory variables during low intensity resistance exercise with blood flow restriction have not been reported.

In turn, an increase in $\mathrm{VO}_{2}$ is evident during and after high intensity resistance exercise. ${ }^{9,10}$ In this type of exercise, the intense cycle of muscle contraction generates blood flow restriction and the accumulation of metabolites. ${ }^{11,12}$ By contrast, in Kaatsu training, the compression of the blood vessels is imposed by pneumatic tourniquets or elastic bands positioned on the distal parts of the limbs.

In this way, is identified a gap in relation to the effects of Kaatsu training on aerobic variables. Thus, becomes necessary to conduct a study that compares aerobic parameters during and after the practice of these two methods and using an exercise protocol that resembles the resistance training prescribed by physical education teachers. Therefore, this study aimed to analyze oxygen consumption and excess post-exercise oxygen consumption under two different resistance-training methodologies: traditional high intensity and low intensity with blood flow restriction.

\section{MATERIALS AND METHODS}

Eight trained men $(25.7 \pm 3$ years; $78.56 \pm 8.17 \mathrm{~kg} ; 1.75 \pm 0.08 \mathrm{~m} ; 14.26 \pm$ 1.75 estimation of fat percentage; $1.42 \pm 0.22$ relative force in the horizontal bench press) between 18 and 30 years participated in the study. The sample dimension was performed using G*Power 3.1 software. ${ }^{13}$ Based on a pilot study, an effect size of 1.9 was found for the $\mathrm{VO}_{2}$. Thus, assuming an estimation error of $a=5 \%$, power $=80 \%$, correlation $=0.5$, number of groups $=2$ (crossover design), and number of measures $=4$, an $n$ of six was necessary.

Inclusion criteria for the subjects were: a) regular practice of resistance exercises for at least one year with three weekly training sessions; b) familiarity with the performance of multi-joint exercises with free weights; c) ability to lift a load greater than or equal to the subject's body mass in the 1RM test for the bench press; and d) absence of use a medications, ergogenic resources and adverse effects of food administered. These criteria ensured that the study sample had experience with resistance training. ${ }^{14}$ Written informed consent was obtained from all participants. The study was approved by the local Ethics Committee (protocol \#0476/13).

Height and body mass were measured with a stadiometer and a balance (Filizola scale, model 31, São Paulo, Brazil) to the nearest 0.5 $\mathrm{cm}$ and $0.1 \mathrm{~kg}$, respectively. To estimate body composition, a tetrapolar bioimpedance device (BIA) was used (Bodystat, Isle of Men, UK).
For the One-Repetition Maximum Test (1RM), primarily, a previous familiarization process was adopted as to the technical gestures demanded by the strength exercises (squat, deadlift, barbell bent-over row, and bench press), on three separate sessions in a 48-hours interval. Composed by three sets of 15-20 repetitions with no overloading and rest interval between series of 90 seconds. After that, in two sessions performed in a 72-hour interval, the subjects performed the one-repetition maximum tests, with an interval of 10 min between each exercise. ${ }^{15,16}$ In both, the subjects estimated their maximum loads in the exercises to be performed. At that time, a warm-up (two sets of 15 repetitions) at 50\% of the estimated load, followed by a 5 -min rest, and then performed the 1RM test, during which up to five attempts could be made. ${ }^{16}$ Load increments range between 5-10\% for the upper-body, and 10-20\% for the lower-body exercises, and the recovery duration between attempts was standardized at 3-5 min.

The test was interrupted once the participant could not properly completed the movement. The maximum load was recorded as the load obtained in the last complete execution of each strength exercise. Was observed if the participant achieves a full range of movement with proficiency for the 1RM lifted to be valid, ${ }^{15,16}$ and all subjects received standardized information on the procedures of the tests and exercise techniques as well as verbal reinforcement. The maximum load of each strength exercise: bench press (112.6 $\pm 23.5 \mathrm{~kg})$, squat (107.1 $\pm 14.6 \mathrm{~kg})$, barbell bent-over row $(92.4 \pm 11.1 \mathrm{~kg})$ and deadlift $(121.6 \pm 25.1 \mathrm{~kg})$.

The $\mathrm{VO}_{2}\left(\mathrm{~mL} \cdot \mathrm{kg}^{-1} \cdot \mathrm{min}^{-1}\right)$ and the HR (beats. $\left.\mathrm{min}^{-1}\right)$ were measured continuously, before, during and after the two protocols by a portable gas analyzer (COSMED ${ }^{\circledR}, \mathrm{K}_{4} \mathrm{~b}^{2}$ Rome, Italy) and a Polar Wireless Double Electrode portable monitor (Kempele, Finland), respectively. The expired gases were continuously measured breath by breath and then averaged as 10 seconds intervals. The equipment was calibrated before each examination according to the manufacturer's guidelines. Ambient temperature and humidity were between 20 and $25^{\circ} \mathrm{C}$ and 40 and $65 \%$, respectively, for all tests. In $24 \mathrm{~h}$ before an exercise session day, the subjects were required to i) avoid caffeine or other metabolic altering supplements drugs; ii) engage in no physical activity; iii) stay well hydrated and not change their habitual diet; and iv) be well rested. The Resting Metabolic Rate (RMR) ( $\left.\mathrm{mL} \cdot \mathrm{kg}^{-1} \cdot \mathrm{min}^{-1}\right)$ was measured, before each experimental session, after a minimum of 12-hour fasting. The measurement was performed with subject lying on a gurney with the recumbent back (35) in an isolated room, with the door closed and lights dimmed. The RMR was measured for 30 minutes and determined from steady-state $\mathrm{VO}_{2}$ values during the last 25 min of measurement. Immediately post exercise, the subjects returned to the same room where was measured the EPOC $\left(\mathrm{mL} \cdot \mathrm{kg}^{-1} \cdot \mathrm{min}^{-1}\right)$ in the same conditions as the RMR.

On the first (test) and second (retest) visits to the laboratory, anthropometrics (test), determination of restriction pressure (test), and 1RM (test and retest) were assessed. The subjects were instructed to maintain their nutritional habits, avoid resistance training and drinking alcohol 72 hours before the tests. There was a week to familiarize the sample with the strength exercises with BFR, and with the use of $K 4 \mathrm{~b}^{2}$, to simulate 
what will be performed in the experimental sessions. Each individual was four times during this week, two for each protocol.

After familiarization and adhering to the 72-hour interval, the first experimental session was conducted, always in the morning, and RMR was measured upon fasting. After that, all participants received the same meals ${ }_{1}^{17}$ composed of $400 \mathrm{ml}$ of natural orange juice (190 kcal), a protein bar of 40 grams (144 kcal), and 150 grams of complex carbohydrate (115 kcal). Elapsed 30 min, a 5-min warm-up was performed, consisting of two sets of 10 repetitions for each exercise (bench press, squat, barbell bent-over row and deadlift) using a 20-kg barbell without blood flow restriction.

Therein, on isolated days (72 hours), randomized protocols were used: (a) traditional high-intensity ${ }^{16}$ at $80 \%$ of 1 RM with eight repetitions and (b) low intensity with blood flow restriction at 20\% of 1 RM with 15 repetitions. In both protocols, three sets were performed a moderate contraction velocity (1 seconds for concentric phase; 1 seconds for eccentric phase), controlled by a metronome, and rest interval of 1 minute. The resistance exercises were performed using free weights, in this order: bench press, squat, barbell bent-over row and deadlift. For the exercises with blood flow restriction, the tourniquet was deflated between the sets and changed from the upper limbs to the lower limbs after ending each exercise.

To determine the restriction pressure the blood pressure was measured in the supine position using a pneumatic tourniquet with a scale up to $700 \mathrm{mmHg}$ (Riester, Jungingen, Germany) for the upper (width $60 \mathrm{~mm}$; length $470 \mathrm{~mm}$ ) and lower limbs (width: $100 \mathrm{~mm}$; length: 540 $\mathrm{mm}$ ), attached to the high axillary and inguinal regions, respectively. The tourniquet was inflated until the auscultatory pulse of the radial or tibial artery was interrupted, using a vascular Doppler probe (MedPeg® DV-2001, Ribeirão Preto, SP, Brazil). ${ }^{18,19}$ Subsequently, $80 \%$ of this value $(\mathrm{mmHg})$, to be applied in the LIRE + BRF, was determined for each participant. The average pressure used throughout the training protocol was $111 \pm 5 \mathrm{mmHg}$ in the upper limbs and $115 \pm 4 \mathrm{mmHg}$ in the lower limbs.

The dependent variables were taken as an average over the values collected at each stage: before (RMR), during $\left(\mathrm{VO}_{2}\right)$ and after (EPOC) theses protocols. For the EPOC, it was measured an average over $5 \mathrm{~min}$, for 30 min after the exercises, totaling six repeated measurements. The total volume load $(\mathrm{kg})$ of exercise session was obtained by multiplying the sets, repetitions, and loads. ${ }^{20}$ All participants completed the protocols.

\section{Statistical Analysis}

The analysis was performed using SPSS software (Chicago, Illinois, USA). The reliability of the $1 \mathrm{RM}$ tests was determined using the intraclass correlation coefficient (ICC). The normality, homogeneity, and sphericity were evaluated. Comparisons between the protocols (LIRE + BFR vs. HIRE) were performed using the general linear model univariate analysis (one-way ANOVA). To analyze the behavior of the $\mathrm{VO}_{2}$ before (RMR) and after (EPOC) the exercise sessions, ANOVA was used for repeated measurements: 2 sessions, LIRE + BFR vs. HIRE (group effect) $x 7$ measures (time effect), using Tukey's post hoc test. The effect size (ES) was classified according to Cohen. ${ }^{21}$ The variation $(\Delta)$ was measured for the dependent variables. The statistical significance was $5 \%$.

\section{RESULTS}

For all of the resistance exercises, the ICC values indicated a high reliability of measurements for the 1 RM test: bench press $=0.997$, squat $=0.969$, barbell bent-over row $=0.980$ and deadlift $=0.984$. The duration of each session (minutes) and volume load $(\mathrm{kg})$ were higher for high intensity protocol compared with low intensity with blood flow restriction $(p=0.001, E S=0.67)$ and $(p=0.001, E S=0.85)$, respectively (Table 1$)$. With regard to $\mathrm{VO}_{2}$, the values during $\mathrm{HIRE}$ were $23 \%$ higher than those for LIRE + BFR ( $p=0.001, E S=0.80)$. Likewise, the heart rate values were higher in HIRE than in LIRE + BFR ( $p=0.001, E S=0.53)$, Table 1.
The RMR and the EPOC (six measurements), analyzed by repeated measure, showed a high effect of time $(p=0.001$, ES $=0.97)$, and group $(p=0.001$, ES $=0.54$ ) (Table 1). For time effect only EPOC in 15 minutes versus EPOC in 20 minutes did not differ $(p=0.264)$ (Figure 1). In addition, there was a strong interaction between time and group ( $p=0.001$, ES = 0.54). The differences observed between the training methods for EPOC was observed up to 25 min of measurement, and were not significantly in the final 5 min (Figure 1).

Only RMR $(p=0.727, E S=0.09)$ and $E P O C$ in minute $30\left(E P O C_{30}\right)$ did not differ between the experimental sessions $(p=0.215$, ES $=0.108$ ) (Table 1). The remaining variables showed higher values for the traditional high intensity protocol, with $\mathrm{EPOC}_{5}(\mathrm{p}=0.004, \mathrm{ES}=0.46)$ and $\mathrm{EPOC}_{10}(\mathrm{p}=0.007$, $E S=0.41)$ presenting the greatest differences between measurements. Similar results were obtained for $\mathrm{EPOC}_{15}(\mathrm{p}=0.004, \mathrm{ES}=0.45), \mathrm{EPOC}_{20}$ $(p=0.003, E S=0.47)$, and $E P O C_{25}(p=0.008, E S=0.40)$.

\section{DISCUSSION}

To the best of our knowledge, this was the first study to determine $\mathrm{VO}_{2}, \mathrm{HR}$, and EPOC using blood flow restriction and multi-joint exercises (bench press, barbell bent-over row, squat, and deadlift). Furthermore, traditional high intensity sessions caused higher oxygen consumption than BFR. In addition, high intensity training volume load was more than double compared to low intensity with blood flow restriction, despite this discrepancy, high intensity training caused an additional increase

Table 1. Descriptive statistics (means, standard deviations, and percentage changes) and inferential tests (GLM univariate) between the two protocols: HIRE vs. LIRE + BRF (group effect).

\begin{tabular}{|c|c|c|c|c|}
\hline Variables & HIRE & LIRE + BFR & $\Delta \%$ & Group effect \\
\hline Time of session $\min$ & $14.8 \pm 1.51^{\ddagger}$ & $18.1 \pm 0.91$ & $22 \%$ & High \\
\hline Volume Load kg & $8.296 \pm 1.230^{\ddagger}$ & $3.907 \pm 568.74$ & $53 \%$ & High \\
\hline $\mathrm{VO}_{2 \mathrm{~mL} \cdot \mathrm{kg}-1 \cdot \mathrm{min}-1}$ & $20.32 \pm 1.46^{\ddagger}$ & $15.65 \pm 1.14$ & $23 \%$ & High \\
\hline $\mathrm{HR}$ beats.min-1 & $146.0 \pm 13.61^{\neq}$ & $119.5 \pm 12.75$ & $18.5 \%$ & High \\
\hline $\mathrm{RMR}_{\mathrm{mL} \cdot \mathrm{kg}-1 \cdot \mathrm{min}-1}$ & $4.56 \pm 0.70$ & $4.43 \pm 0.71$ & $2.9 \%$ & Low \\
\hline EPOC $5 \mathrm{~mL} \cdot \mathrm{kg}-1 \cdot \mathrm{min}-1$ & $15.92 \pm 0.83^{\neq}$ & $13.89 \pm 1.42$ & $12.8 \%$ & High \\
\hline EPOC $10 \mathrm{~mL} \cdot \mathrm{kg}-1 \cdot \mathrm{min}-1$ & $8.05 \pm 1.08^{\ddagger}$ & $6.59 \pm 0.73$ & $18.1 \%$ & High \\
\hline EPOC15 mLkg-1.min-1 & $7.31 \pm 0.67^{\ddagger}$ & $6.20 \pm 0.61$ & $15.2 \%$ & High \\
\hline EPOC20 mLkk-1.min-1 & $7.19 \pm 0.64^{\neq}$ & $6.08 \pm 0.60$ & $15.4 \%$ & High \\
\hline EPOC $25 \mathrm{~mL} \cdot \mathrm{kg}-1 \cdot \mathrm{min}-1$ & $6.67 \pm 0.51^{\ddagger}$ & $5.87 \pm 0.52$ & $12 \%$ & High \\
\hline $\mathrm{EPOC} 30_{\mathrm{mL} \cdot \mathrm{kg}-1 \cdot \mathrm{min}-1}$ & $6.21 \pm 0.46$ & $5.87 \pm 0.56$ & $5.5 \%$ & Low \\
\hline
\end{tabular}

$H I R E=$ high intensity resistance exercise; $L I R E+B F R=$ low intensity resistance exercise with blood-flow restriction $\mathrm{HR}=$ heart rate; $\mathrm{RMR}=$ resting metabolic rate; $\mathrm{EPOC} 5=$ measured between 0 and 5 minutes; $\mathrm{EPOC} 10=$ measured between 5 and 10 minutes; EPOC15 = measured between 10 and 15 minutes; EPOC20 $=$ measured between 15 and 20 minutes; EPOC25 = measured between 20 and 25 minutes; EPOC 30 = measured between 25 and 30 minutes. ${ }^{*}$ Significant difference between the protocols (HIRE vs. LIRE + BFR) at the $5 \%$ level.

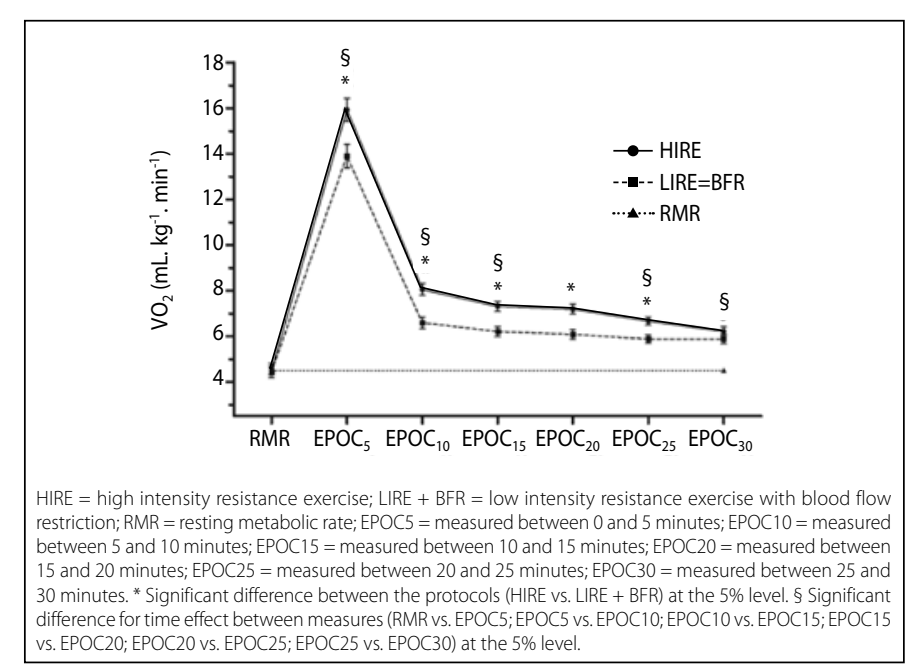

Figure 1. Oxygen consumption (VO2) before (RMR) and after (EPOC) the randomized resistance training sessions. 
in $\mathrm{VO}_{2}$ of only $23 \%$, indicating that the use of blood flow restriction may also have attenuated the difference between the total work.

Manuscripts have shown that aerobic exercise (e.g., ergometric bicycle $^{3}$ and walking ${ }^{3,4,6,7}$ ) performed with blood flow restriction increases $\mathrm{VO}_{2}$, EPOC, relative intensity, ${ }_{1}^{6}$ minute ventilation and heart rate, ${ }^{7} \mathrm{com}-$ pared with protocols without blood flow restriction. This may be due to decreased blood flow caused during BFR, with reduced intramuscular distribution of oxygen, ${ }^{22}$ oxygen supply to the muscles ${ }^{23}$ and in post exercise there is an increase in venous compliance impeding that arterial inflow to be reduced. ${ }^{24}$

In this hand, heart rate, cardiac output, stroke volume, and blood pressure responses to resistance (leg press 20\% 1RM) and aerobic (treadmill walking $4 \mathrm{Km} \cdot \mathrm{min}-1$ ) blood flow restriction exercise were greater than control exercise (without BFR). ${ }^{25}$ Moreover, in this study, traditional high intensity sessions produced a $\mathrm{VO}_{2}$ of $8 \mathrm{kcal} \cdot \mathrm{min}^{-1}$, whereas low intensity with blood flow restriction sessions presented $6.2 \mathrm{kcal} \cdot \mathrm{min}^{-1}$. During EPOC, these differences decreased, the lowest variations between the protocols were observed over this period, high intensity training produced the higher EPOC up to 25 minutes, after this, the values did not differ between the two methods. Previous studies have indicated that $\mathrm{VO}_{2}$ during traditional resistance training presents higher variation, i.e., between 3 and $11 \mathrm{kcal} \cdot \mathrm{min}-1,26,27$ and might reach $30 \mathrm{kcal} \cdot \mathrm{min}-1 .{ }^{28}$ With regard to the measurement of HR, LIRE + BFR reached $61 \%$ of the maximum HR, with an average of 119.5 beats.min-1. The HIRE produced an average of 146 beats.min-1, which corresponds to $75 \%$ of the maximum HR.

Has also been demonstrated the positive effect of blood flow restriction on ventilatory measures in predominantly aerobic exercises.
In walking the oxygen consumption, energy expenditure and heart rate was significantly higher with blood flow restriction. ${ }^{29,30}$ Staunton et al..$^{25}$ found that the acute hemodynamic responses of both resistance exercise (a leg press trial) as well as aerobic exercise (treadmill trail) evoked an increased heart rate from baseline to exercise and this was higher for blood flow restriction in comparison with a control exercise. Nevertheless, whether these results forecast physiological changes over time is unknown, this fact is another limitation of this study, since variables were not monitored over long periods of time.

The presents data on resistance training sessions consisting of multi-joint exercises and alternating upper- and lower-body exercises, and this protocol was similar to that applied by teachers working in the area, indicating that high intensity training $\left(8 \mathrm{kcal} \cdot \mathrm{min}^{-1}\right)$ using double of the total volume load was $23 \%$ more efficient than low intensity with blood flow restriction $\left(6.2 \mathrm{kcal} \cdot \mathrm{min}^{-1}\right)$. This suggests that blood flow restriction may have attenuated the differences between the protocols.

\section{CONCLUSION}

In conclusion, traditional high intensity had a stronger effect than low intensity with blood flow restriction on $\mathrm{VO}_{2}$, EPOC and $\mathrm{HR}$ indicating greater ventilatory stress. In addition, the protocols were tested using a sequence of multi-joint resistance exercises with free weights, which are similar to those taught by teachers, practiced in gyms, which can provide some guidance when prescribing or executing resistance training with blood flow restriction.

All authors declare no potential conflict of interest related to this article.

AUTHORS' CONTRIBUTIONS: Each author contributed individually and significantly to the development of this article. ATAJ (0000-0002-3857-681X)*: article writing, work drawing and data collection; MSCS (0000-0001-5566-3248)*: data analysis, article writing and final approval; GRN (0000-0001-8477-1993)*: statistical analysis and interpretation of data; RP (0000-0002-7590-3015)*: writing and review of article; GVN (0000-0003-4027-966X)*: data collection and article writing; NDG (0000-0002-8105-7580)*: critical and grammatical review of the article; JVA (0000-0001-5399-7797): project supervision and final approval. *ORCID (Open Researcher and Contributor ID).

\section{REFERENCES}

1. Fahs CA, Loenneke JP, Rossow LM, Thiebaud RS, Bemben MG. Methodological considerations for blood flow restricted resistance exercise. J Trainol. 2012;1(1):14-22.

2. Karabulut M, Abe T, Sato Y, Bemben MG. The effects of low-intensity resistance training with vascular restriction on leg muscle strength in older men. Eur J Appl Physiol. 2010;108(1):147-55.

3. Abe T, Fujita S, Nakajima T, Sakamaki M, Ozaki H, Ogasawara R, et al. Effects of low-intensity cycle training with restricted leg blood flow on thigh muscle volume and VO2max in young men. J Sports Sci Med. 2010;9(3):452-8

4. Abe T, Kearns CF, Sato Y. Muscle size and strength are increased following walk training with restricted venous blood flow from the leg muscle, Kaatsu-walk training. J Appl Physiol (1985). 2006;100(5):1460-6

5. Abe T, Sakamaki M, Fujita S, Ozaki H, Sugaya M, Sato Y, et al. Effects of Low-Intensity Walk Training With Restricted Leg Blood Flow on Muscle Strength and Aerobic Capacity in Older Adults. J Geriatr Phys Ther. 2010;33(1):34-40.

6. Mendonca GV, Vaz JR, Pezarat-Correia P, Fernhall B. Effects of Walking with Blood Flow Restriction on Excess Post-exercise Oxygen Consumption. Int J Sports Med. 2015.

7. Mendonca GV, Vaz JR, Teixeira MS, Grácio T, Pezarat-Correia P. Metabolic cost of locomotion during treadmill walking with blood flow restriction. Clin Physiol Funct Imaging. 2014;34(4):308-16.

8. Tanimoto M, Madarame H, Ishii N. Muscle oxygenation and plasma growth hormone concentration during and after resistance exercise: Comparison between "KAATSU" and other types of regimen. Int KAATSU Training Res. 2005;1(2):51-6.

9. Simão R, de Salles BF, Figueiredo T, Dias I, Willardson JM. Exercise order in resistance training. Sports Med. 2012;42(3):251-65.

10. Sousa MSC, Araújo Júnior AT, Lima Neto AJ, Vilaça-alves J, Fernandes HM, Reis VM. Effects of movement speed and intensity on fast excess postexercise oxygen consumption of bench press and half squat exercises performed to failure. J Sports Med Phys Fitness. 2013;53(Suppl 1):18-24.

11. Ferretti G. Maximal oxygen consumption in healthy humans: theories and facts. Eur J Appl Physiol 2014;114(10):2007-36.

12. Ruiter CJ, Goudsmit JF, Van Tricht JA, de Haan A. The isometric torque at which knee-extensor muscle reoxygenation stops. Med Sci Sports Exerc. 2007;39(3):443-53.

13. Faul F, Erdfelder E, Lang AG, Buchner A. G* Power 3: A flexible statistical power analysis program for the social, behavioral, and biomedical sciences. Behav Res Methods. 2007;39(2):175-91.

14. Keogh JWL, Wilson GJ, Weatherby RE. A cross-sectional comparison of different resistance training techniques in the bench press. J Strength Cond Res. 1999;13(3):247-58.

15. ACSM ACoSM. ACSM's Guidelines for Exercise Testing and Prescription. $9^{\circ}$ ed. Philadelphia, PA: Lippincott Williams \& Wilkins, 2013.

16. Garber CE, Blissmer B, Deschenes MR, Franklin BA, Lamonte MJ, Lee IM, et al. American College of
Sports Medicine position stand. Quantity and Quality of Exercise for Developing and Maintaining Cardiorespiratory, Musculoskeletal, and Neuromotor Fitness in Apparently Healthy Adults: Guidance for Prescribing Exercise. Med Sci Sports Exerc. 2011;43(7):1334-59

17. Alves JV, Saavedra F, Simão R, Novaes J, Rhea MR, Green D, et al. Does aerobic and strength exercise sequence in the same session affect the oxygen uptake during and postexercise? J Strength Cond Res. 2012;26(7):1872-8.

18. Gualano B, Ugrinowitsch C, Neves M Jr, Lima FR, Pinto AL, Laurentino G, et al.Vascular occlusion training for inclusion body myositis: a novel therapeutic approach. J Vis Exp. 2010;5(40).

19. Laurentino GC, Ugrinowitsch C, Roschel H, Aoki MS, Soares AG, Neves M, Jr, et al. Strength training with blood flow restriction diminishes myostatin gene expression. Med Sci Sports Exerc. 2012;44(3):406-12

20. Scott BR, Duthie GM, Thornton HR, Dascombe BJ. Training Monitoring for Resistance Exercise: Theory and Applications. Sports Med. 2016;46(5):687-98.

21. Cohen J. Statistical Power Analysis for the Behavioral Sciences. $2^{\circ}$ ed. New Jersey, USA: Lawrence Erlbaum Associates, 1988.

22. Takano H, Morita T, lida H, Asada K, Kato M, Uno K, et al. Hemodynamic and hormonal responses to a short-term low-intensity resistance exercise with the reduction of muscle blood flow. Eur J Appl Physiol. 2005;95(1):65-73.

23. Coza A, Dunn JF, Anderson B, Nigg BM. Effects of compression on muscle tissue oxygenation at the onset of exercise. J Strength Cond Res. 2012;26(6):1631-7.

24. Patterson SD, Ferguson RA. Enhancing strength and postocclusive calf blood flow in older people with training with blood-flow restriction. J Aging Phys Act. 2011;19(3):201-13.

25. Staunton CA, May AK, Brandner CR, Warmington SA. Haemodynamics of aerobic and resistance blood flow restriction exercise in young and older adults. Eur J Appl Physiol. 2015;115(11):2293-302.

26. Bloomer RJ. Energy cost of moderate-duration resistance and aerobic exercise. J Strength Cond Res. 2005;19(4):878-82.

27. Phillips WT, Ziuraitis JR. Energy cost of the ACSM single-set resistance training protocol. J Strength Cond Res. 2003;17(2):350-5.

28. Reis VM, Júnior RS, Zajac A, Oliveira DR. Energy Cost of Resistance Exercises: an Uptade. J Hum Kinet 2011;29A:33-9.

29. Loenneke JP, Thrower AD, Balapur A, Barnes JT, Pujol TJ. The energy requirement of walking with restricted blood flow. Sport Sci. 2011;4(2):7-11.

30. Park SY, Kwak YS, Harveson A, Weavil JC, Seo KE. Low intensity resistance exercise training with blood flow restriction: insight into cardiovascular function, and skeletal muscle hypertrophy in humans. Korean J Physiol Pharmacol. 2015;19(3):191-6. 